\title{
Analytical Methods in the Quality Control of Scientific Publications Part III: Publishers' Ethics and Editors' Complicity
}

\author{
Ilia Brondz \\ Norwegian Drug Control and Drug Discovery Institute (NDCDDI) AS, Ski, Norway \\ Email: ilia.brondz@gmail.com \\ Received 13 July 2014; revised 12 August 2014; accepted 19 September 2014 \\ Copyright (C) 2014 by author and Scientific Research Publishing Inc. \\ This work is licensed under the Creative Commons Attribution International License (CC BY). \\ http://creativecommons.org/licenses/by/4.0/ \\ (c) (i) Open Access
}

\section{Abstract}

In 2012, the first paper in the series Analytical Methods in Quality Control of Scientific Publications was published in the American Journal of Analytical Chemistry, Vol. 3, No. 6, 2012, pp. 443-447. This paper was mainly based on evidence presented in the 2011 in book Historical Overview of Chromatography and Related Techniques in Analysis of Antimalarial Drug Primaquine (editor Ilia Brondz, Nova Science Publishers, Inc., ISSN 978-1-61761-944-1). The first paper in this series discussed issues of obvious falsification and plagiarism contained in paper published by Dongre $e t$ al., Applications of GC-EI-MS for the Identification and Investigation of Positional Isomer in Primaquine, an Antimalarial Drug. Journal of Pharmaceutical and Biomedical Analysis, Vol. 39, No. 1-2, 2005, pp. 111-116. Dongre et al. copied their publication from an original research manuscript submitted for consideration by other authors. This paper was published in the Asian Journal of Chemistry, Vol. 17, No. 3, 2005, pp. 1678-1688. Conclusive arguments against the publication of Dongre et al. were presented in the American Journal of Analytical Chemistry, Vol. 3, No. 6, 2012, pp. 443-447. Further cases of general plagiarism and incompetence relating to authors, reviewers, editors, and publishers were presented in Part II in Analytical Methods in Quality Control of Scientific Publications Part II: The Authors', Reviewers', Editors' Responsibility and the Publishers' Authority in the International Journal of Analytical Mass Spectrometry and Chromatography, Vol. 1, No. 2, 2013, pp. 81-89. The present paper will discuss the following issues: the obvious neglect of the rights of authors by some publishers and editors; how original research manuscripts are exposed to mediocre researchers, and possibly sold, by editors to these "scientists" to boost the image of these particular "scientists"; how the order of authors' names in published articles are changed to satisfy the commercial interests of companies; and how copyright is breached in an appalling way by well-established publishers. The documents presented here concern research publications in the fields of chromatography, chromatography-mass spectrometry, and mass spectrometry. 
Keywords

Publishers' Ethics, Editors' Complicity, Breach of Copyright, Plagiarism, Falsification, Fraud, Chromatography, Mass Spectrometry

\section{Introduction}

\subsection{The Phenomenon of Plagiarism and the Current Situation}

Plagiarism is the main transgression that offends many authors and undermines the publication of research reports and even research itself. However, what lies behind this term "plagiarism”? It is like the king in Hans Christian Andersen's fairy tale, “The Emperor's New Clothes”. The king is naked and he himself can see this. The citizens, members of society, ministers and others can also see that the king is naked but they are all afraid to tell the truth because they fear being seen as acting outside the mainstream.

In the particular case of scientific plagiarism, the reasons for silence are many, but they are not the subject of this article. Instead, the broader (deeper) meaning of plagiarism will be discussed—plagiarism is simple cheating, falsification, forgery, stealing, filching, pinching and similar actions. For example, it might be acknowledged that there is a perceived difference between "flawed data" being published (reflecting poorly conducted research and a weak peer-review system) and "falsified data" being published (deliberate professional misconduct, as well as the same weak peer-review system).

In the recent, very public case in Japan (Haruko Obokata), the word "manipulation" was commonly used to describe the "misconduct". Clearly, the semantics around plagiarism is a central issue and requires careful consideration.

People who plagiarize are acting like common thieves. However, in educated "gentlemanly" society, instead of using the caddish word thief, it is better to use the more polite term "plagiarist". Looking up the definition of the term "plagiarist" in Lexipedia http://www.lexipedia.com/, we find "someone who uses another person's words or ideas as if they were his own". However, is this definition sufficient? Of course, it is not; the term "swindler" could also be included and used. The term "swindler/swindling" is a derogatory showing a critical attitude to somebody's reputation and affairs. How does such a phenomenon persist in educated "gentlemanly" society?

\subsection{The Environment That Tolerates Plagiarism}

A suitable environment is required for the existence of any phenomenon. Just as in “The Emperor's New Clothes”, lies/swindling can only persist if the suitable conditions exist. After the discovery that the publication by Dongre et al. was obviously "stolen goods" and that Dongre et al. had submitted another fake publication as (Dongre, V.G., Karmuse, P.P., Rao, P.P., Kumar, A. (2008) Development and validation of UPLC method for determination of primaquine phosphate and its impurities, Journal of Pharmaceutical and Biomedical Analysis, Vol. 46, No. 2, pp. 236-242). Dr. Brondz contacted the Editor-in-Chief (EIC) of JPBA, Mister Bezhan Chankvetadze, requesting an explanation. In reply to Mister Chankvetadze, Mister Dongre produced evasive, unprofessional explanations. However, the documents from this latter exchange with Mister Dongre were useful in providing an exhaustive evaluation published in [1] and [2] that publication [3], as well as many other publications exposed in [4] are unreliable. Publications [3] and [5] by Dongre et al. were falsifications or stolen goods from manuscript to publication [6]. Several attempts were made to publish in JPBA a critical paper disclosing the falsifications published in [3], and other paper by Dongre. However, all attempts were rejected with the following line of argument from reviewers supported by Mister Chankvetadze: "This manuscript might contain some interesting scientific information, but I believe the editors of this journal (as well as the publisher) cannot publish it in JPBA in its present form due to the following reasons:

... The manuscript is written too offensive towards pharmaceutical industry, as well as towards other scientific group(s). The manuscript submitted to this journal has to focus strictly on the scientific findings and mentioning if these results agree with previously published data by these or other authors" (The text in italics is part of the document published in [2]).

These sentiments are the essence of the existing environment that helps to propagate plagiarism: 
1) Even if a manuscript has some interesting scientific information, it will not be considered for publication by the editors... (as well as the publisher) if it contains criticism of the industry or other scientific group(s).

2) The main criterion for a good manuscript to be published is that it has to focus strictly on the scientific findings, which implies that no criticism can be made about the unreliability of facts presented by industry or other scientific group(s). Also it must not there be a sign of criticism towards the pharmaceutical industry, as well as towards other scientific group(s).

3) A very important demand made to authors is that if they wish their paper to be published, they must "review their results and data in relation to the existing literature" and declare the consent with previous published data, mentioning if these results agree with previously published data by these or other authors. The intention here is to avoid conflict with existing state-of-the-art and maintain the status quo. Noting whether one's research results agree with previously published data by the author or other authors is, of course, a good idea. However, what if the results contradict previously published data by the author or other authors, or previously declared data by industry? Take the controversial case of the drug thalidomide and the data that were declared by the drug company Chemie Grünenthal the information that conduced to (... the thalidomide holocaust http://ffdn.se/web/chemie-grnenthal-1/). As we now know, thousands of infants were born with severe deformities resulting from the manufacturer only publishing favorable data.

The case of Dr. Linda Buck is an example of cheating by means of flawed data: (In 2008, Dr. Linda Buck at Fred Hutchinson Cancer Research Center retracted a paper she and her co-workers had published in Nature in 2001 describing experiments on the mouse olfactory cortex done by a former postdoctoral researcher in her lab, Dr. Zhihua Zou. Buck and her colleagues subsequently reviewed two other papers her lab had published describing Zou's experiments on odor responses in olfactory cortex, one published in PNAS in 2005 and the other published in Science in 2006. They were unable to reproduce key findings in both papers. In addition, they found figures inconsistent with original data in the PNAS paper. Buck has therefore simultaneously retracted both the PNAS and Science paper). The text in italics is part of the document published in

http://retractionwatch.com/2010/09/23/nobelist-linda-buck-retracts-two-studies-on-olfactory-networks-and-the-n ews-is-embargoed/. Buck was awarded the 2004 Nobel Prize in Physiology or Medicine. However, a short time after the presentation ceremony, she was confronted with more accurate measurements and data. It appeared that Buck was awarded the Nobel Prize for flawed data. To save face, the Nobel Prize Committee decided that Buck should keep the Prize, despite falsified/forged data and despite breaching the rules of the Nobel Prize Committee: (We also tried to find out whether Nobel Prize committees keep tabs on retractions by Nobelists. The committees responsible for the physics and chemistry prizes, and in economics, probably don't, we were told, but we haven't heard back about medicine or physiology). The text in italics is part of the document published in http://retractionwatch.com/2010/09/23/nobelist-linda-buck-retracts-two-studies-on-olfactory-networks-and-the-n ews-is-embargoed/. Furthermore, she was elected Fellow of the American Academy of Arts and Sciences in 2008. In response to the controversy, "all blame was put on the laboratory assistant Dr. Zhihua Zou" this clearly illustrates the prevailing environment and a tolerance within scientific community toward fraud and falsification of high-ranked individuals.

There is much criticism of plagiarism in many journal and publications. The best example is perhaps from the EIC of Analytical Chemistry, Mister Royce Murray, in his editorial There Can Be Shame and Punishment in Copy and Paste [7]. It is an example of logomachy and the apparently "high ethical standards" of Mister Murray, according to whom, it is forbidden to republish even a small portion of an author's own previously published work even with sufficient citation. The author of this paper (Dr. Brondz) submitted to Mister Murray for publication in Analytical Chemistry the text of [1]. It could not be published in Analytical Chemistry because of "criticism towards... by naming the offenders by name". Therefore, we see that although Mister Murray is critical of the phenomenon, it is nevertheless forbidden to name offenders by names. A similar position is prevalent among most EICs such as Mister Murray and Chankvetadze.

\section{Breach of Author Copyright by Editors and Publisher Fraud}

\subsection{Negligence Concerning Authors' Rights}

In many cases, authors are helpless when they are confronted with the arrogance of some EICs and publishers. Here are some examples. 


\subsection{Case 1}

The following paper appeared in Trends in Chromatography published by Research Trends: Separation of the positional isomer quinocide from the anti-malaria drug primaquine using a Discovery ${ }^{\circledR}$ HS-F5 HPLC column by I. Brondz, D. Ekeberg, L. Karaliova, I. Jennings, J. A. Hustad, R. Svendsen [8]. Later, it appeared that on the Internet the paper was presented with a somewhat different order of author names (see Figure 1): Ian Jennings, Larysa Karaliova, Robert Svendsen, Dag Ekeberg, Jan Arild Hustad, Ilia Brondz.

In the table of contents for the original hard-copy publication and in the paper itself, yet another sequence of author names was given: Ilia Brondz is the corresponding and first-named author (see Figure 2) because as the senior researcher, he initiated the project and he funded the project.

Correspondence with the publisher on this matter and demands to correct the order of the list of contributors given on the Internet in commercial advertising to original were fruitless.

Research Trends is an India-based publisher. There are sufficient grounds to believe that the publication culture in India is "different" and ethical standards in publishing lower than in the US or Europe.

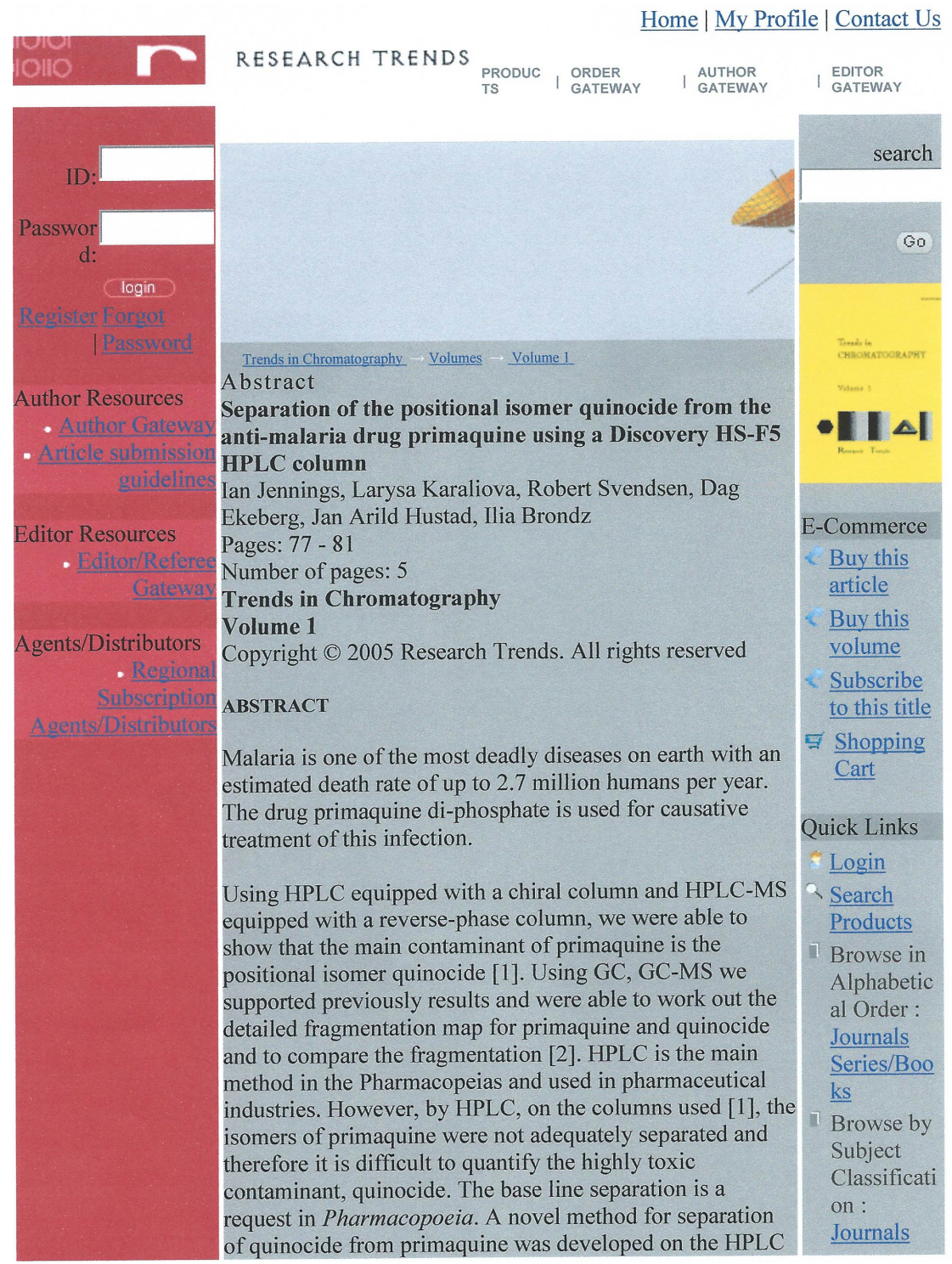

Figure 1. The paper was presented on the Internet http://researchtrends.net/tia/abstract.asp?in=0\&vn=1\&tid=60\&aid=1967\&pub=2005\&type=3 with a different order of authorship. 


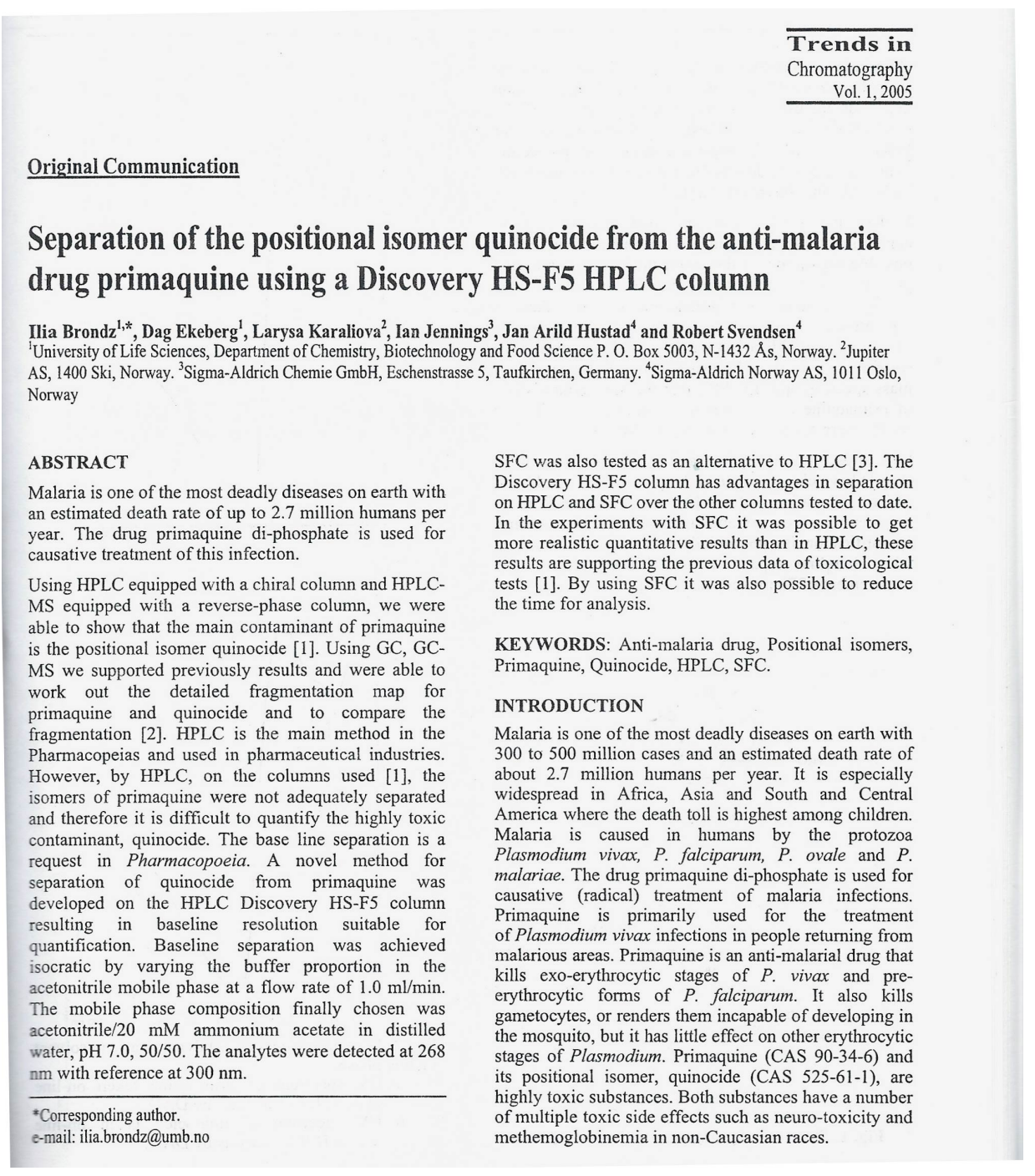

Figure 2.The original hard copy of the paper [8] with a correct order of authorship.

However, let us compare the behavior of an Asian publisher with a US or European publisher. The second case concerns the direct breach of author copyright by a US publisher.

\subsection{Case 2}

In general, Asian publishers are less experienced in the publication industry and abide less by the law and rules; moreover, the existence of corruption is well known especially in India and good publication practices are not always followed. What is the situation with a US-based publisher? The general belief is that US publishers follow the law and rules to the letter.

However, this following example illustrates just the opposite. The publisher is Nova Science Publishers Inc., 400 Oser Avenue, Suite 1600 Hauppauge, NY, 11788-3619.

The author in question was invited by the publisher to submit a chapter for publication in a book entitled Antimalarial Drugs: Costs, Safety and Efficacy (editors Csizmadia, E., Kalnoky, I.) (Figure 3) with the chapter title SFC-MS analysis of contaminants in primaquine diphosphate tablets and spectral UV and NMR characterizing of primaquine and quinocide [9].

The title page claims the publisher's copyright (Figure 4). What are about the rights of the author or the obligations of the publisher toward an author and his research publication Figure 5 ?

To the great surprise of the author of Chapter V [9], he received the following e-mail: 


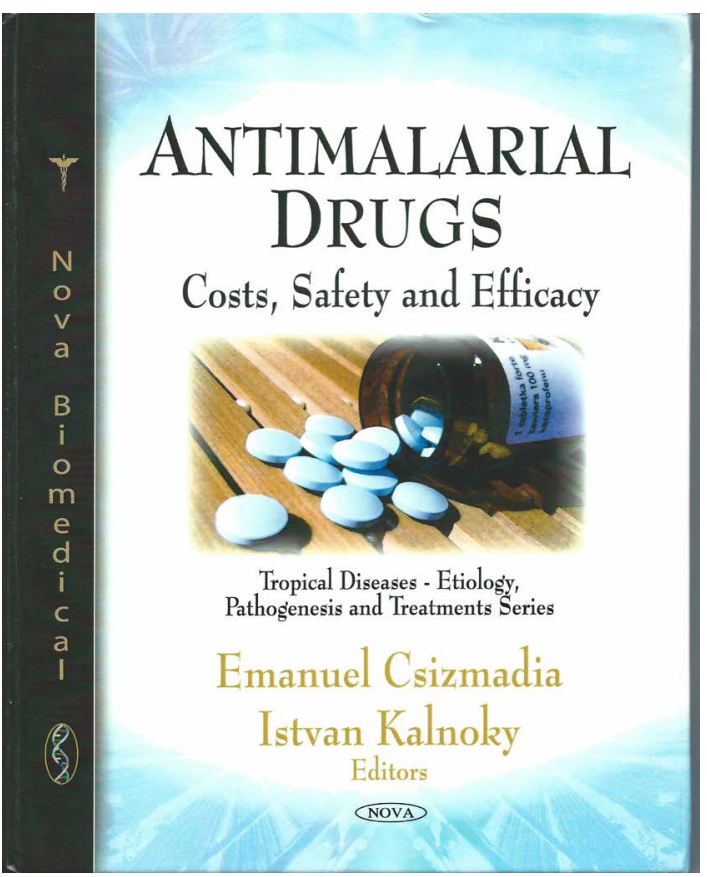

Figure 3. The book Antimalarial Drugs: Costs, Safety and Efficacy [9].

Copyright (C) 2009 by Nova Science Publishers, Inc.

All rights reserved. No part of this book may be reproduced, stored in a retrieval system or transmitted in any form or by any means: electronic, electrostatic, magnetic, tape, mechanical photocopying, recording or otherwise without the written permission of the Publisher.

For permission to use material from this book please contact us:

Telephone 631-231-7269; Fax 631-231-8175

Web Site: http://www.novapublishers.com

\section{NOTICE TO THE READER}

The Publisher has taken reasonable care in the preparation of this book, but makes no expressed or implied warranty of any kind and assumes no responsibility for any errors or omissions. No liability is assumed for incidental or consequential damages in connection with or arising out of information contained in this book. The Publisher shall not be liable for any special, consequential, or exemplary damages resulting, in whole or in part, from the readers' use of, or reliance upon, this material. Any parts of this book based on government reports are so indicated and copyright is claimed for those parts to the extent applicable to compilations of such works.

Independent verification should be sought for any data, advice or recommendations contained in this book. In addition, no responsibility is assumed by the publisher for any injury and/or damage to persons or property arising from any methods, products, instructions, ideas or otherwise contained in this publication.

This publication is designed to provide accurate and authoritative information with regard to the subject matter covered herein. It is sold with the clear understanding that the Publisher is not engaged in rendering legal or any other professional services. If legal or any other expert assistance is required, the services of a competent person should be sought. FROM A DECLARATION OF PARTICIPANTS JOINTLY ADOPTED BY A COMMITTEE OF THE AMERICAN BAR ASSOCIATION AND A COMMITTEE OF PUBLISHERS.

\section{Library of Congress Cataloging-in-Publication Data}

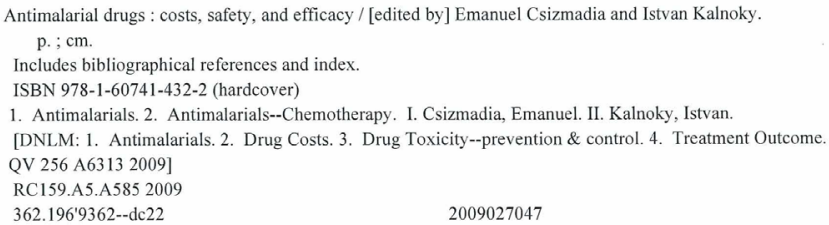

Published by Nova Science Publishers, Inc: t-New York

Figure 4. Copyright for the book Antimalarial Drugs: Costs, Safety and Efficacy. 
In: Antimalarial Drugs: Costs, Safety and Efficacy Editors: Emanuel Csizmadia and Istvan Kalnoky
ISBN: 978-1-60741-432-2

(C) 2009 Nova Science Publishers, Inc.

\title{
SFC-MS Analysis of Contaminants in Primaquine Diphosphate Tablets and Spectral UV and NMR Characterising of Primaquine and Quinocide
}

\author{
Ilia Brondz* \\ Department of Biology, University of Oslo, P.O. Box 1066, \\ Blindern, 0316 Oslo, Norway
}

\begin{abstract}
In the Pharmacopoeias, characterization of the toxic contaminant in primaquine is not described. The Pharmacopoeias require chromatographic separation Rs greater than 2 between the contaminant and API peak, based on separation using HPLC. The United States Pharmacopeia (USP) and The National Formulary (NF) seek submission of a monograph proposing an improvement of analysis of primaquine phosphate tablets.

In this study, resolution based on supercritical fluid chromatography (SFC) and supercritical fluid chromatography-mass spectrometry (SFC-MS) satisfy the Pharmacopoeia standards.

Primaquine diphosphate $7.5 \mathrm{mg}$ tablets were analyzed. Separation Rs greater than 2 was achieved between the major contaminant peak and the peak of the API in less than 15 minutes. The novelty of this work is the determination of the main contaminant in medical form primaquine diphosphate tablets.

Keywords: SFC-MS, Primaquine; Quinocide; Anti-malaria drug; Contaminations in primaquine tablets.
\end{abstract}

* Corresponding author: Department of Biology, University of Oslo, P.O. Box 1066, Blindern, 0316 Oslo, Norway, Phone: +47228573 53, Mobile: +4793814864, E-mail: ilia.brondz@bio.uio.no

Figure 5. Chapter V [9] published in Antimalarial Drugs: Costs, Safety and Efficacy.

deeann jehning < $\underline{\text { deeann@ieonline.com }>}$

$12 / 4 / 13$

to ilia.brondz, me

Dear Dr. Brondz,

I am trying to track down an article that you wrote but I've not had any luck finding the journal in libraries.

The citation is:

Journal of Malaria Research vol 2 no 2-3 pp 181-200

SF-MC analysis

Brondz I 
Would you be able to provide me with a copy of this paper?

Many thanks for your help.

DeeAnn Jehning

Information Express

565 Middlefield Road

Menlo Park CA 94025

559-562-2768

deeann@ieonline.com

The answer to Dr. Deeann Jehning is reproduced below:

08.12.13

Dear Dr. Deeann Jehning

deeann@ieonline.com

I have following information on your question:

1) Please go to the link: https://www.novapublishers.com/catalog/product_info.php?products_id=40600

2) Volume 2 Issue 2-3 (Journal of Malaria Research)

3) SFC-MS Analysis of Contaminants in Primaquine Diphosphate Tablets and Spectral UV and NMR Characterising of Primaquine and Quinocide

Ilia Brondz

This paper was published in the journal without of my permission and knowledge. I will appreciate you for more comprehensive information. It is possible that the paper is a reprint of the chapter in the book which was published by Nova before.

Please feel free to contact me if you have any questions!

Sincerely yours,

Prof. Ilia Brondz PhD., Sc.D.

Director of Jupiter Ltd., Norway

E-mail: ilia.brondz@gmail.com

Website: http://www.brondz.com

The examination of the case gave the following results: the paper "SFC-MS analysis of contaminants in primaquine diphosphate tablets and spectral UV and NMR characterizing of primaquine and quinocide" was published in the Journal of Malaria Research by Nova Science Publishers Inc.

https://www.novapublishers.com/catalog/product_info.php?products_id=40600\&osCsid=a886371244a4c7a723e 3568167ecc5c8 also https://www.novapublishers.com/catalog/product info.php?products id=40600. The name of the author was given as Ilia Brondz (see Figure 6), despite the fact that Ilia Brondz had not submitted a manuscript for consideration to be published in the above journal and no copyright transference agreement was signed with Dr. Brondz. This publication can be described practically as a pirate publication. Letters to Nova Science Publishers Inc. from Dr. Brondz with a request to provide him with the text of this paper and explain publication of paper went unanswered. All attempts to retrieve a copy of this paper with the help of the University of Oslo library were without success. Dr. Brondz has no knowledge of the content of this paper. According to the EIC of Analytical Chemistry, Mister Murray [7], if more than 50 words of a previously published work are copied, this amounts to shameful plagiarism that should be punished.

What do we call the act of a publisher passing off a previously published book chapter as a new paper without even informing the author and without his knowledge of what the text is about, and without receiving the author's copyright permission?

Damage to a scientist's (author's) reputation can be enormous, but the money the author has to pursue a legal case against the publisher, as well as the money the publisher has for its defense measure the possibility of defending the author's rights. Without doubt, the author has no chance of winning against the publisher in that case. This case is a clear example of piracy on the part of publishers and the lack of defense of authors.

\subsection{Case 3}

The India-based publisher Research Trends is a small and not very well-known publisher. The US-based publisher Nova Science Publishers Inc. is a medium-sized publisher but well known for avoiding paying royalties to its authors. 
Journal of Malaria Research

Volume 2, Issue 2-3, 2011, Pages 181-200

SFC-MS analysis of contaminants in

primaquine diphosphate tablets and spectral

UV and NMR characterising of primaquine

and quinocide

Brondz, I.

Department of Biology, University of Oslo, P.O. Box 1066 Blindern, 0316 Oslo, Norway

View references

\begin{abstract}
In the Pharmacopoeias, characterization of the toxic contaminant in primaquine is not described. The Pharmacopoeias require chromatographic separation Rs greater than 2 between the contaminant and API peak, based on separation using HPLC. The United States Pharmacopeia (USP) and The National Formulary (NF) seek submission of a monograph proposing an improvement of analysis of primaquine phosphate tablets. In this study, resolution based on supercritical fluid chromatography (SFC) and supercritical fluid chromatography-mass spectrometry (SFC-MS) satisfy the Pharmacopoeia standards. Primaquine diphosphate $7.5 \mathrm{mg}$ tablets were analyzed. Separation Rs greater than 2 was achieved between the major contaminant peak and the peak of the API in less than 15 minutes. The novelty of this work is the determination of the main contaminant in medical form primaquine diphosphate tablets. (C) Nova Science Publishers, Inc.
\end{abstract}

Author keywords

Anti-malaria drug; Contaminations in primaquine tablets; Primaquine; Quinocide; SFC-MS

Indexed keywords

EMTREE drug terms: primaquine derivative; primaquine diphosphate; quinocide; unclassified drug

EMTREE medical terms: accuracy; article; controlled study; drug contamination; drug dosage form comparison; mass spectrometry; nuclear magnetic resonance spectroscopy; standard; supercritical fluid chromatography; tablet formulation; ultraviolet spectroscopy

Chemicals and CAS Registry Numbers: primaquine diphosphate, 63-45-6; quinocide, 525-61-1

Manufacturers:Drug manufacturer: Sigma Aldrich, Germany.

ISSN: 19395906Source Type: Journal Original language: English

Document Type: Article

Brondz, I.; Department of Biology, University of Oslo, P.O. Box 1066 Blindern, 0316 Oslo, Norway;

(C) Copyright 2013 Elsevier B.V., All rights reserved.

Figure 6. The Journal of Malaria Research did not sign a copyright agreement with Dr. Brondz to publish this paper.

Let us now turn to European publishers with a long tradition in the field, since it was in Europe that the culture of publishing books [10], journals, and papers was first established. There are two giants-Springer and Elsevier - with a long history and a keen interest in promoting their own ethical performance.

The book Chromatography of Aroma Substances and Fragrances (author Tibor Cserháti) published by SpringerVerlag contains a total of 130 figures. About one-third of the book content consists of reproduced figures. For example, on page 320, Figure 4.2 is reproduced from J. Chromatography A, 1148 (2007) [11]. As with all other figures reproduced in this book [12], permission to reprint was acknowledged by (Figure 4.2 Reprinted with permission from...).

The corresponding author of [11] was surprised by the statement, because he personally never gave permission to reproduce his figure; he was not even asked to give permission to reproduce this figure. He contacted the coauthors of [11], to inquire whether any of them had given permission to reprint. All coauthors were also surprised by the news that permission had been given to reproduce the figure. The main falsification was thus the statement that the figure had been reproduced with permission from Brondz et al. It was an outright falsification. When Dr. Brondz contacted Tibor Cserháti for an explanation, Mister Cserháti replied that he had a license to reproduce the artwork and he furnished this document with genuine piece of cheating. A copy of the license is shown in Figure 7(a) and Figure 7(b). A careful examination of the license reveals that it was given to-and paid for by 
Rightslink Printable License

This is a License Agreement between Institute of Material and Environmental Chemistry ("You") and Elsevier ("Elsevier") provided by Copyright Clearance Center ("CCC"). The license consists of your order details, the terms and conditions provided by Elsevier, and the payment terms and conditions.

\begin{tabular}{|c|c|}
\hline Supplier & $\begin{array}{l}\text { Elsevier Limited } \\
\text { The Boulevard, Langford Lane } \\
\text { Kidlington,Oxford, OX5 IGB, UK }\end{array}$ \\
\hline Registered Company Number & 1982084 \\
\hline Customer name & $\begin{array}{l}\text { Institute of Material and } \\
\text { Environmental Chemistry }\end{array}$ \\
\hline \multirow[t]{2}{*}{ Customer address } & Pusztaszeri 59/67 \\
\hline & Budapest, other 1525 \\
\hline License Number & 2125871399671 \\
\hline License date & Feb 11, 2009 \\
\hline Licensed content publisher & Elsevier \\
\hline Licensed content publlcation & Journal of Chromatography A \\
\hline Licensed content title & $\begin{array}{l}\text { The real nature of the indole } \\
\text { alkaloids in Cortinarius infractus: } \\
\text { Evaluation of artifact formation } \\
\text { through solvent extraction } \\
\text { method development }\end{array}$ \\
\hline Licensed content author & $\begin{array}{l}\text { Ilia Brondz, Dag Ekeberg, Klaus } \\
\text { Høiland, David S. Bell and Amy R. } \\
\text { Annino }\end{array}$ \\
\hline Licensed content date & 27 April 2007 \\
\hline Volume number & 1148 \\
\hline Issue number & 1 \\
\hline Pages & 7 \\
\hline Type of Use & Book / Textbook \\
\hline Requestor type & Academic / Educational \\
\hline Portion & Figures/table/illustration/abstracts \\
\hline Format & Electronic \\
\hline You are an author of the Elsevier article & No \\
\hline Are you translating? & No \\
\hline Order Reference Number & \\
\hline Title of your book & $\begin{array}{l}\text { Chromatography of aroma } \\
\text { substances and fragrances }\end{array}$ \\
\hline Publisher of your book & Springer \\
\hline
\end{tabular}


Expected publication date

Estimated size of your book (pages)

Elsevier VAT number

Billing Type

Company

Billing Address

Customer reference info

Permissions price

Value added tax $15 \%$

Total

Terms and Conditions
Nov 2009

350

GB 494627212

Invoice

Institute of Material and Environmental Chemistry

Pusztaszeri 59/67

Budapest, other 1525

Hungary

17.25 USD

2.59 USD

$(1.79 E)$

19.84 USD

Gratis licenses (referencing $\$ 0$ in the Total field) are free. Please retain this printable license for your reference. No payment is required.

If you would like to pay for this license now, please remit this license along with your payment made payable to "COPYRIGHT CLEARANCE CENTER" otherwise you will be invoiced within $\mathbf{4 8}$ hours of the license date. Payment should be in the form of a check or money order referencing your account number and this invoice number

RLNK10584706.

Once you receive your invoice for this order, you may pay your Invoice by credit card. Please follow instructions provided at that time.

Make Payment To:

Copyright Clearance Center

Dept 001

P.O. Box 843006

Boston, MA 02284-3006

If you find copyrighted material related to this license will not be used and wish to cancel, please contact us referencing this license number 2125871399671 and noting the reason for cancellation.

Questions? customercare@copyright.com or +1-877-622-5543 (toll free in the US) or $+1=978$-646-2777.

(b)

Figure 7. (a) The first page of the license was given to Institute of Material and Environmental Chemistry in Budapest. (b) The second page of the license was given to Institute of Material and Environmental Chemistry in Budapest.

— the Institute of Material and Environmental Chemistry in Budapest, but not to Tibor Cserháti. The Institute of Material and Environmental Chemistry in Budapest was not the author of the book [12]. Cserháti had no legal 
right to reproduce the artwork because the license was not issued in his name. Three legal provisions were violated in this case:

1) Cserháti published artwork from [11] without permission; there is no guarantee that any of the other 130 figures were published with permission.

2) By publishing the written falsified statement concerning permission to reproduce artwork from [11] as (Reprinted with permission from Brondz et al.), Cserháti publicly offended the author of [11].

3) Springer-Verlag published artwork from [11] without having the right to do this, because the author Tibor Cserháti did not have a license issued to him to do so.

Dr. Brondz applied to the publisher Elsevier as copyright holder to settle the case and protect the author's rights.

06.08.10

David Sleeman (Publisher)

Analytical Chemistry \& Sensors

Elsevier Ltd.

The Boulevard

Langford Lane

Kidlington

OX5 1AS, Oxford, UK

David Sleeman D.sleeman@elsevier.com

Dear Sir,

A week ago I send to you an e-mail with a request about your and Elsevier's opinion: "Was a license given to Tibor Cserháti or not”. License 2125871399671 was given to the Institute of Material and Environmental Chemistry, which is not the author of the book "Chromatography of Aroma Compounds and Fragrances". No one believes that this license was given to Mr. Cserháti, the author of the same title (ISBN 978-3-642-01655-4). Do you accept that the use of graphic art from J. Chromatography A, 1148 (2007) 1-7 by Mr. Tibor Cserháti was illegal?

Best regards,

Dr. Ilia Brondz

Department of Biology

University of Oslo

Norway

R\&D Department

Jupiter AS,

Norway

The reply (Figure 8) was unprofessional and misleading:

"It appears that he (Tibor Cserháti) did indeed act properly in asking for permission and the date on the licence of February 11, 2009 would suggest that he did it more than eighteen months ago. The date printed on the bottom of the page you sent me is merely the date that the Rightslink web page was copied from the website and has nothing to do with the licence date. I hope that this information puts your mind at rest".

It is clear from Figure 7(a) and Figure 7(b) that the license was not given to the author of [12]. The text between ELSEVIER LICENSE TERMS AND CONDITIONS (title) and the double lines at the bottom of the document is a legally binding text. Careful examination of the text of the license shows the date given as July 26, 2010 (see the upper right corner under the title ELSEVIER LICENSE TERMS AND CONDITIONS and above the double lines at the top of document). The explanation given (The date printed... has nothing to do with the licence date) is thus a genuine lie.

There are also other contradictions, namely the "license" presented to the authors of [11] is missing a signature, stamp or seal to ensure the document's genuine origin.

The publisher Springer-Verlag refused to answer on the accusation of publishing the book for the author without a license to reproduce the artwork or regarding the inclusion of the false statement Reprinted with permission from Brondz et al. (2007).

This account is a good example of the dubious ethical practices of the "big" publishers such as Springer-Verlag and Elsevier. 
Sleeman, David G (ELS-OXF) <D.sleeman@elsevier.com>

$8 / 6 / 10$

to

Dear Dr. Brondz,

Apologies for not responding to your e-mail on Monday before now, but I did immediately forward it to colleagues for clarification.

I have now received notification that Tibor Cserhti did indeed follow the correct procedure using

Rightslink which is an online service used by scientific and technical publishers, editors and authors to gain copyright permission. The only mistake Tibor made was to pay for permission as he didn't need to. Our rights and permissions department tell me that he checked the wrong box when requesting permission, but was charged the lowest possible price of $\$ 19.84$ (including tax) which is merely an administrative fee anyway and not a profit making concern for Elsevier.

It appears that he did indeed act properly in asking for permission and the date on the licence of February 11, 2009 would suggest that he did it more than eighteen months ago. The date printed on the bottom of the page you sent me is merely the date that the Rightslink web page was copied from the website and has nothing to do with the licence date.

I hope that this information puts your mind at rest that every proper procedure has been followed, but let me know if you have any other concerns.

Wishing you an enjoyable weekend,

David

Figure 8. E-mail from David Sleeman (Elsevier).

\subsection{Case 4}

Publication [1] presented exhaustive evidence concerning the falsifications by Dongre et al. in [3] and [5]. The main evidence presented in [1] was the fact that Dongre et al. did not possess a sample of quinocide that had been either donated or synthesized in their laboratory at the time before of writing, at the time of writing and at the time after writing of [3]. How were they able to analyze a substance they did not possess? Additional evidence presented in [2] supports the accusation that the text of [6] was shown to Dongre et al. before [6] was published in AJC.

\subsubsection{Case 4: History of Publication}

The story started with an invitation to submit a manuscript for consideration for publication. This invitation came from Mister Agarwal, EIC of AJC. The manuscript for [6] was received by AJC on September 11, 2004. The paper was accepted officially for publication on October 1, 2004 with written confirmation by Mister Agarwal (Figure 9). The publication should have been included in Vol. 17, No. 2 of AJC, but it was delayed to be published in Vol. 17, No. 3 (September 2005) (see Figure 10). Why was there a need to prevent publication of [6] within the normal time frame? It was necessary to enable the publication of the "stolen goods" [3], which was accepted officially for publication on March 24, 2005. The publication of [6] was delayed and the acceptance date for [6] in AJC was falsified to be March 28, 2005 (Figure 11(k)) instead of October 1, 2004 (Figure 9).

\subsubsection{Case 4: Falsification and Fraud of Mister Agarwal and Colleagues}

The corresponding author asked for an explanation about the delay in publication from Mister Agarwal (see Figure 10).

However, his explanation was evasive, as the following will demonstrate. The falsification and fraud of Mister Agarwal and colleagues were a clear case of misconduct for a number of reasons:

1) Only one of the papers appearing in Vol. 17, No. 2 of AJC was accepted for publication on October 1, 2004. All other papers were accepted later than this date (the date of acceptance of [6]).

2) The last paper published in Vol. 17, No. 2 was accepted as late as February 9, 2005.

3) A total number of 120 papers were published in Vol. 17, No. 2; 119 of them were accepted for publication after [6].

4) The acceptance date more or less agreed with the line of publication printed in the Vol. 17, No. 2 and No. 3.

5) The first paper in Vol. 17, No. 3 was accepted for publication as late as February 11, 2005.

What could be the explanation for a paper accepted on October 1, 2004 being published after the other 284 papers that were accepted at later dates for volume 17, and transferred to the later published issue? The answer is obvious: It was necessary to give to paper [6] the falsified acceptance date of March 28, 2005 (see Figure 11(k)). It was also necessary to give priority for publication to the plagiarized (stolen goods) paper by Dongre et al. on March 24, 2005 [3]. A comparison of the acceptance dates on the documents in Figure 9 and Figure 11(k) with 
(Established in 1989)

Phone (91) (0120) 2630138, From Delhi : 9511-2630138

ISSN 0970-7077

ASIAN JOURNAL OF CHEMISTRY

(An International Quarterly Research Journal of Chemistry)

11/100, Rajendra Nagar, Sector 3, Sahibabad - 201005 (Ghaziabad) INDIA

email : ajchem@indiatimes.com

www : asianjournalofchemistry.com

Editor-in-Chief

Dr. R.K.AGARWAL

Managing Editor / Circulation Manager Mrs. PUSHPA AGARWAL

Date $01-1-10-104$

Ph.D., D.Sc

Prof. Ilia Brondz

Department of Molecular Biosciences

University of Oslo

P.O. Box. 1041, Blindern

0316 Oslo, NORWAY

Dear Prof. Ilia Brondz,

We glad to inform you that your research manuscript Nos. 4278/2004 entitled, "Nature of the main contaminant in the drug primaquine di-phosphste :GC-MS analysis" has been accepted for publication in Asian Journal of Chemistry. The paper will appear in Volume 17 (2005) issue of Asian Journal of Chemistry. Here, we are enclosing an invoice bill No. 312 dated $1^{\text {st }}$ October 2004 of . USD 300=00 (US Dollars Three Hundred only) towards the Printing /Publication and Membership Charges.

So, we request you to please remit the payment at your earliest as possible of our bill in favour of Asian Journal of Chemistry. Your early response will be highly appreciated.

Thanks

Sincerely Yours<smiles>C1CCCOCC1</smiles>

Dr. Himanshu Agarwal

Executive Editor

Figure 9. Confirmation of acceptance for publication in AJC.

To: ilia.brondz@imbv.uio.no

Subject: Asian Journal of chemistry

Dear Prof.llia Brondz,

Although I put your request to our publishing committee to include your papers in current issue of Asian Journal of chemistry. i.e. in Volume 17 No. 2 (2005) issue. We have received the explanation from our publishers that the in the last moments after finalizing the contents of volume 17 No. 2 (2005)issue, lot of requests have been forwarded to include their respective papers in the coming issue. It was not possible to include all the papers (around 50 papers from various authors)to include their papers, as will lead to delay in the release of the Journal, which is against our policy.

And moreover, the publisher has assured us to release the next issue at earliest. Hope that now you will be satisfied with the reply and continue to contribute your suggestions/research manuscript also.

regards

Dr. Himanshu Agarwal

Executive Editor

Asian JOurnal of Chemistry

Thanks

Sincerely Yours

Dr. Himanshu Agarwal

Asian Journal of Chemistry - Executive Editor

www.geocities.com/ajchem 1988

Figure 10. Letter from Mister Agarwal. 


\title{
Nature of the Main Contaminant in the Drug Primaquine Diphosphate: GC-MS Analysis
}

\author{
ILIA BRONDZ*, UWe KLEIN, DIMITRIS MANTZILAS, DAG EKEBERZ $\dagger$ \\ ERLEND HVATTUM $\dagger$, HENRK SCHULTZ $\ddagger$ and FELIX MIKHAILITSYN** \\ Department of Molecular Biosciences \\ University of Oslo, P.O. Box 1041, Blinde n, 0316 Oslo, Norway \\ Tel.: (47)22857726; Fax: (47)22854443; E-mail: ilia.brondz@biokjemi.uio.no
}

\begin{abstract}
In the present work, GC-MS was used to provide evidence on fragmentation differences between primaquine and quinocide. Primaquine and quinocide are readily separated by GC. Both substances give visible $\mathrm{M}^{+}$molecular ion $259 \mathrm{~m} / \mathrm{z}$. The base peak in the mass spectrum of primaquine was found to be at $\mathrm{m} / \mathrm{z} 201$, in the mass spectrum of the positional-isomer quinocide the base peak was found to be at $\mathrm{m} / \mathrm{z} 187$. Two detailed MS fragmentation schemes for primaquine and quinocide are provided which can help to identify primaquine-like derivatives. Using GC-MS, it is possible to recognize with high confidence the positional-isomer contaminant in gas chromatograms of the antimalaria drug primaquine without a standard substance as reference.
\end{abstract}

Key Words: Primaquine, Quinocide, MS fragmentation, GC-MS.

\section{INTRODUCTION}

Malaria is one of the most widely spread diseases on the globe with an estimated case rate of about $300-500$ million and a death rate of about 2.7 million humans per year. The microorganisms that cause malaria in humans are Plasmodium falciparum, $P$. vivax, $P$. ovale and $P$. malariae. Primaquine (CAS 90-34-6) and quinocide (CAS 525-61-1) are the only anti-malarial drugs ${ }^{1}$, which are gametocidal and effective against the hypnozoites and against the tissue schizonts. Primaquine is not effective against blood schizonts ${ }^{2}$.

Anti-malarial drugs had been synthesized in Germany and France before World War II, and in Great Britain, the USA and the USSR during and since World War $\mathrm{II}^{3}$. Elderfield et al. ${ }^{4}$ have developed a procedure for the synthesis of primaquine,

†Department of Chemistry and Biotechnology, Section Chemistry, Agricultural University of Norway, P.O. Box 5040, 1432 Ås, Norway.

‡Weifa AS, Hausmanns gt. 6, P.O. Box 9113, Gronland, 0133 Oslo, Norway.

**Martsinovsky Institute of Medical Parasitology and Tropical Medicine, 20 Malaja Pyrogovskaja St., Moscow, Russia.

(a) 
which later was improved by Elderfied et al. $^{5}$ Synthesis of quinocide was developed and later improved by Braude and Stavrovskaya ${ }^{6,7}$.

The drug primaquine phosphate is listed as "primaquine phosphate and enantiomer" for the first time in the British Pharmacopoeia ${ }^{8}$. In the British Pharmacopoeia 1993 addendum $1997^{9}$ and in the 3rd edition of the European Pharamacopoeia, it is stated that related substances are allowed to be present in the drug at a maximum of $3 \%{ }^{10}$. These limits were still valid in the British Pharmacopoeia $2000^{11}$ and in European Pharmacopoeia 3rd, supplement $2001^{12}$.

It has been assumed for a long time that the main contaminant of primaquine is its enantiomer. A possible separation of the racemate has been reported ${ }^{4}$. In an earlier publication it is shown by using liquid chromatography-mass spectrometry (LC-MS) that the main contaminant of primaquine is not its enantiomer but the positional isomer quinocide. Identifying contaminants in human medicines is important, especially for highly toxic compounds. When a standard is not readily available, as is the case for quinocide, it is necessary to look for alternative provided methodology to improve the reliazility of the analysis.

Primaquine (CAS 90-34-6) and quinocide (CAS 525-61-1) are highly toxic substances, which can have a number of side effects upon treatment. Quinocide is difficult to obtain as a standard due to a halt in production of the substance in the former USSR, which was the only producer of quinocide. Because the UV spectrum and MS fragmentation under HPLC-MS analysis of primaquine and quinocide are closely related, it is difficult to prove the identity of quinocide without a standard. The identity of contaminants in human medicine is important, especially for high toxic substances; therefore we looked for alternative ways to identify quinocide in samples. An MS fragmentation spectrum during GC-MS provides more detail and more information than MS fragmentation spectra during HPLC-MS, giving substantial knowledge about differences in closely related molecules.

We used GC-MS to show fragmentation differences between primaquine and quinocide; we also worked out fragmentation schemes for both substances. MS fragmentation of primaquine is well studied, but MS fragmentation of quinocide is poorly covered in the literature. Fragmentations were not compared to date and characteristic fragments which can be used to distinguish between the two substances are not yet described.

\section{EXPERIMENTAL}

Primaquine diphosphate p.a. quality standard from Aldrich (Aldrich-Chemie, Steinheim, Germany) and p.a. quality standard quinocide dihydrochloride from Dr. F. Mikhailitsyn (Martsinovsky Institute of Medical Parasitology and Tropical Medicine, Moscow, Russia) were analyzed.

\section{Preparation of primaquine and quinocide for GC-MS}

Primaquine diphosphate and standard quinocide dihydrochloride were used. 5 $\mathrm{mg}$ of each substance were dissolved in $10 \mathrm{~mL}$ of purified water and $1 \mathrm{~mL}$ of concentrated ammonia, p.a. grade (Merck, Darmstad, Germany), was added.

The base was extracted in $10 \mathrm{~mL}$ of spectroscopic grade hexane (Merck). The 
hexane extract was concentrated to $1 \mathrm{~mL}$ by $\mathrm{N}_{2}$ before $\mathrm{GC}-\mathrm{MS}$ analysis. The extract was protected from light.

\section{Gas chromatography-mass spectrometry GC-MS}

The setup consisted of an HP 6890N gas chromatograph from Agilent Technologies Inc. (Agilent Technologies Inc, Wilmington, England) connected to the MS such that the column was entering directly into the ion source of the MS. The temperature in the GC-MS interface was kept at $300^{\circ} \mathrm{C}$ and helium was used as the carrier-gas. Samples were injected by a combi-PAL from CTC Analytics AG (Zwingen, Switzerland). The flow rate was in the range of $2.31 \mathrm{~mL} / \mathrm{min}$ at a constant pressure of 713 torr. The MS instrument was operated in the electron impact (EI) mode at $70 \mathrm{eV}$ utilizing an ion source temperature of $210^{\circ} \mathrm{C}$. The pressure in the ion source was 6-10 torr and the pressure in the analyzer was 7-10 torr. Chromatographic separation was achieved by temperature programming: $120^{\circ} \mathrm{C}$ hold $1 \mathrm{~min}$, then $5^{\circ} \mathrm{C} / \mathrm{min}$ until $270^{\circ} \mathrm{C}$.

Chromatography was performed on an HP 5 fused-silica capillary column, 30 $\mathrm{m}$ long, with $320 \mu \mathrm{m}$ I.D. and $0.25 \mu \mathrm{m}$ film thickness, produced by $\mathrm{J} \& \mathrm{~W}$ Scientific Inc., CA, USA.

The injector was a split/splitless injector operated in split mode with the temperature set up to $300^{\circ} \mathrm{C}$. The sample volume was $0.2 \mu \mathrm{L}$. The mass spectrometer (MS) used was an AutoSpec Ultima from Waters produced by Micromass Ltd., Manchester, England. The MS is a three sector instrument with EBE-geometry.

\section{RESULTS AND DISCUSSION}

Appearance of a positional isomer in synthesis of primaquine is possible ${ }^{1}$. There are two possible positional isomers. One isomer has the methyl group in position $\mathrm{C}_{1}$ of the chain, the other in position $\mathrm{C}_{4}$.

As, due to a halt in production of the substance in the former USSR, the quinocide is difficult to obtain as a standard, it seemed necessary to look for methods that allow identifying quinocide in the absence of a standard substance.

The data show that evidence for the main contaminant quinocide can be provided by GC-MS even in the absence of a standard substance.

\section{GC-MS}

The drug primaquine and the authentic standard quinocide were analyzed with GC-MS. MS was set to the scanning mode. Fig. 1 shows the reconstructed ion chromatograms (RIC): A of the drug primaquine, B of the standard quinocide and $\mathrm{C}$ of the co-chromatography of the drug primaquine with standard quinocide. In Fig. 1A there are two peaks, peak $a$ is primaquine and peak $b$ the contaminant (positional isomer quinocide). In Fig. 1B there is one peak, which is the quinocide standard. In Fig. $1 \mathrm{C}$ the results of co-chromatography of the drug primaquine with standard quinocide is shown. Peak a corresponds to primaquine and peak $b$ corresponds to quinocide (see also Fig. 1A). All substances were detected as the molecule ions with $\mathrm{m} / \mathrm{z} 259$. Figs. $2 \mathrm{~A}$ and $\mathrm{B}$ show the mass spectra of the two 
Vol. 17, No. 3 (2005)

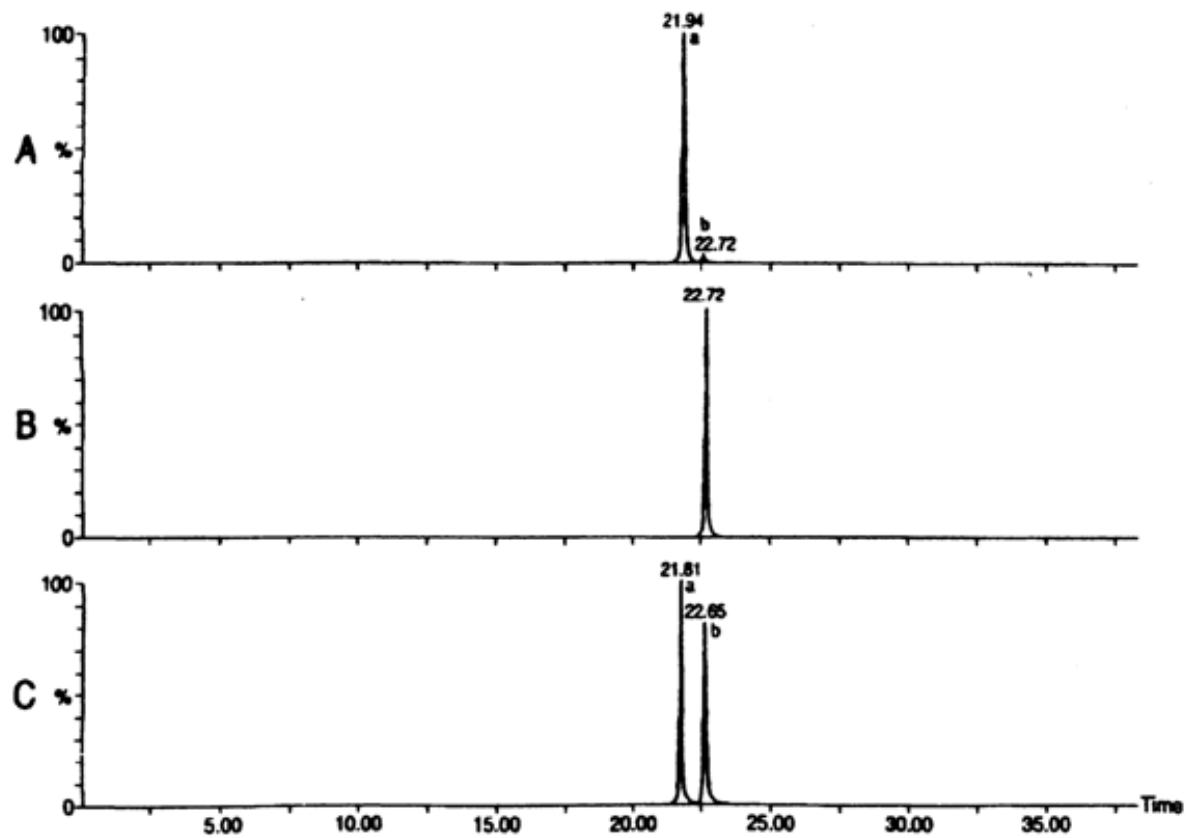

Fig. 1. Reconstructed ion chromatograms (RIC): A of the drug primaquine, B of the standard quinocide and $\mathrm{C}$ or the co-chromatography the drug standard quinocide. The gas chromatograph used was an HP 6890N from Agilent Technologies Inc., Wilmington, England connected to the MS. The mass spectrometer MS used was an AutoSpee Ultima from Waters produced by Micromass Ltd., Manchester, England. The MS is a three sector instrument with EBE-geometry

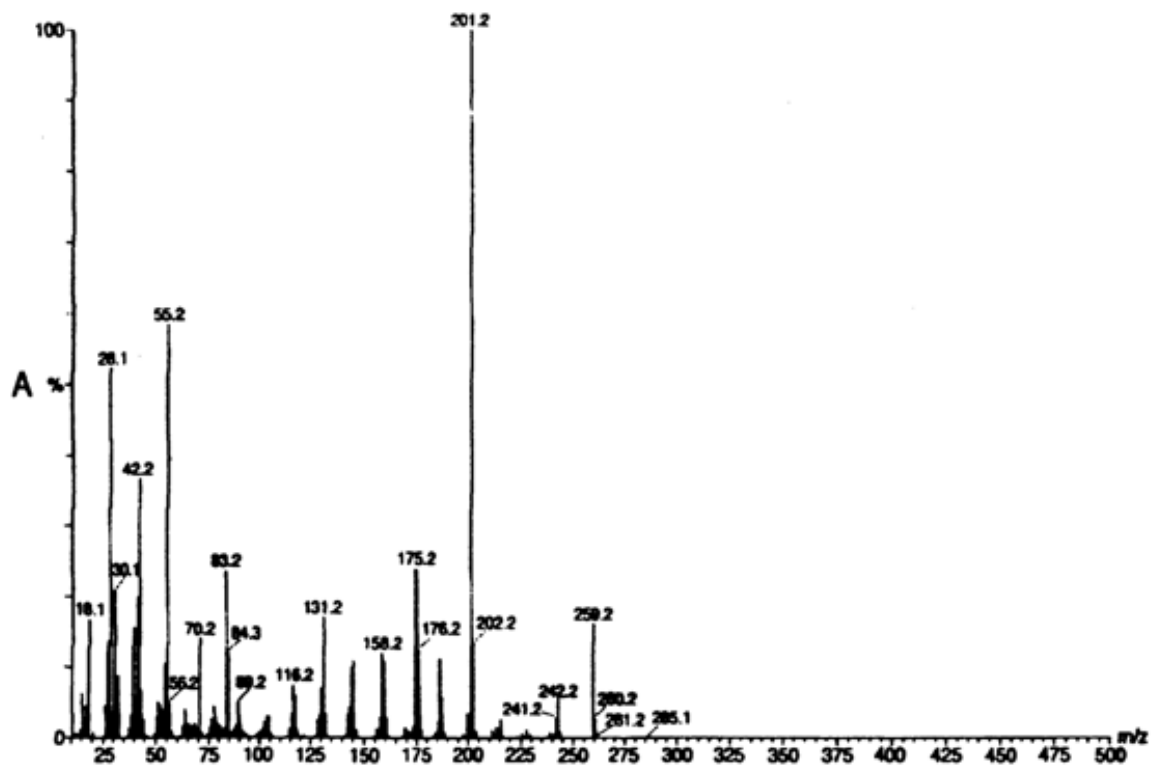

(A)

Fig. 2. The mass spectra of the two peaks found in the drug primaquine: A. the mass spectrum found in the peak a;

(d) 
peaks found in the drug primaquine, and Fig. $2 \mathrm{C}$ shows the mass spectrum of the peak found in the quinocide standard. In Fig. 1C the results of co-chro-
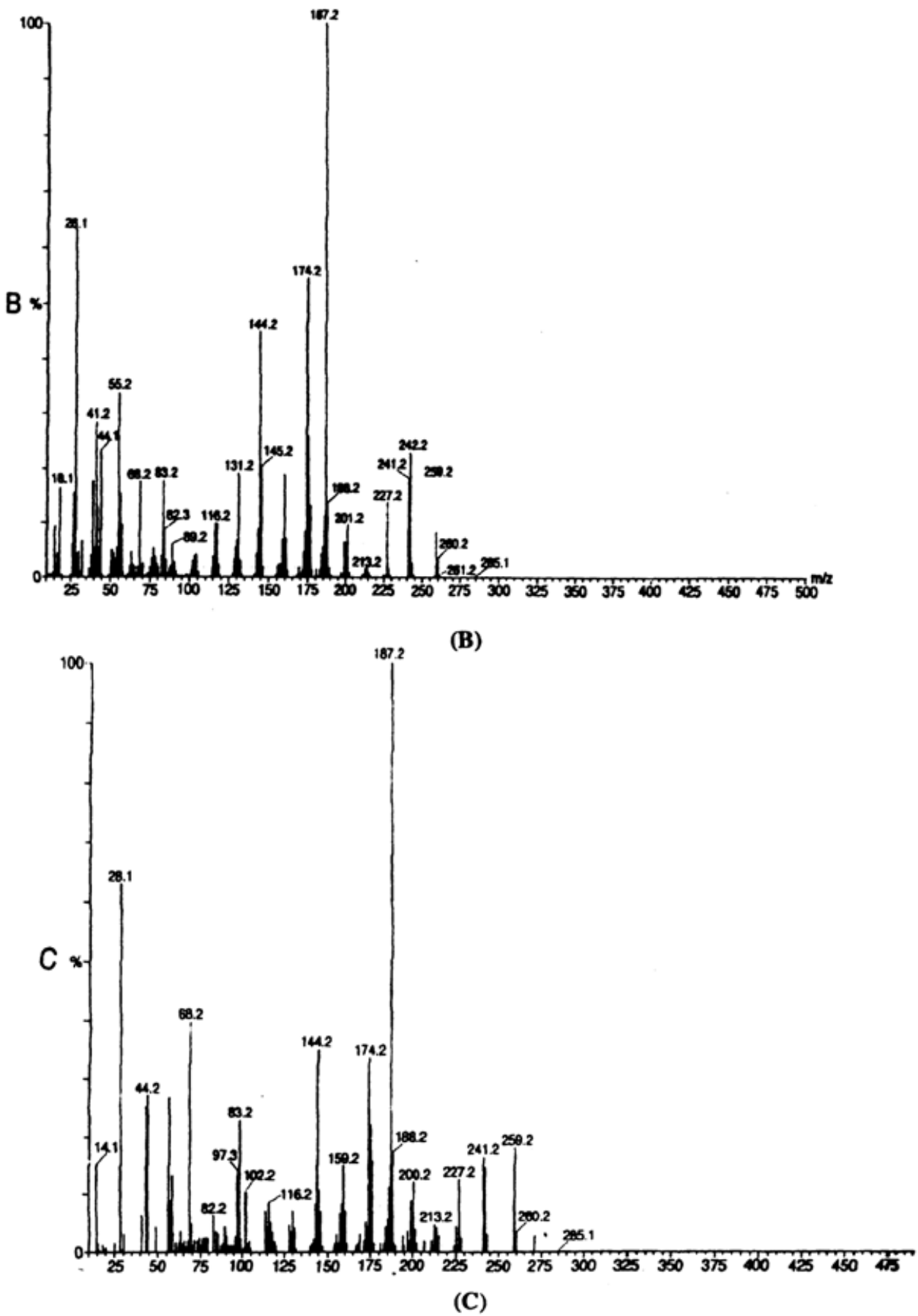

Fig. 2. The mass spectra of the two peaks found in the drug primaquine: $B$. the mass spectrum found in the peak b (Fig. 1A); C. the mass spectrum found in the quinocide (Fig. 1B);

(e) 

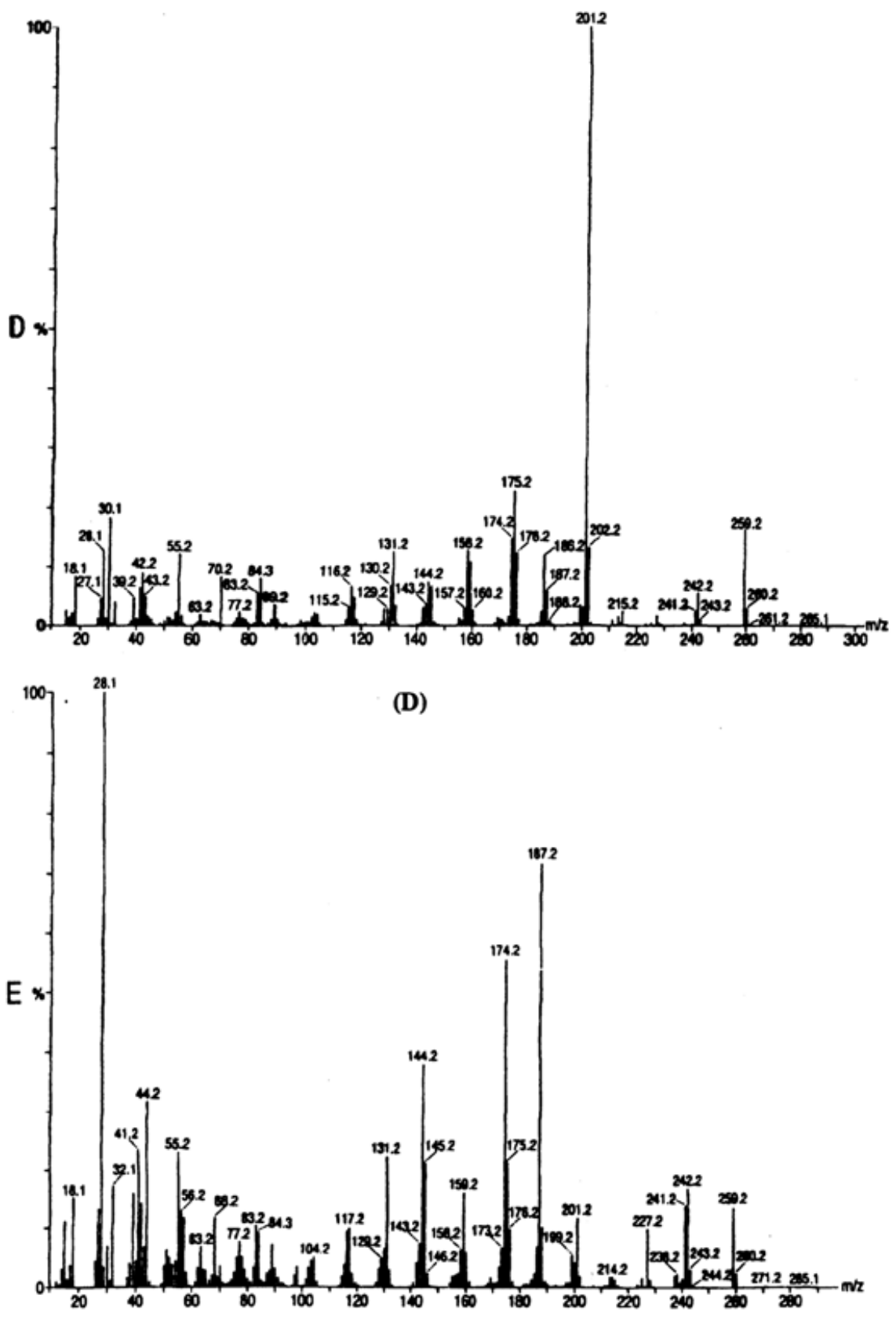

(D)

Fig. 2. The mass spectra of the two peaks found in the drug primaquine: $D$. the mass spectrum found in the peak a; $\mathbf{E}$. the mass spectrum found in the peak b (Fig. 1C) using mass spectrometer AutoSpec Ultima.

matographythe mass spectra of peak a is identical qualitatively and quantitatively to primaquine (Fig. 2D), and the mass spectrum of peak $b$ is identical qualitatively and quantitatively to quinocide (Fig. 2E). 


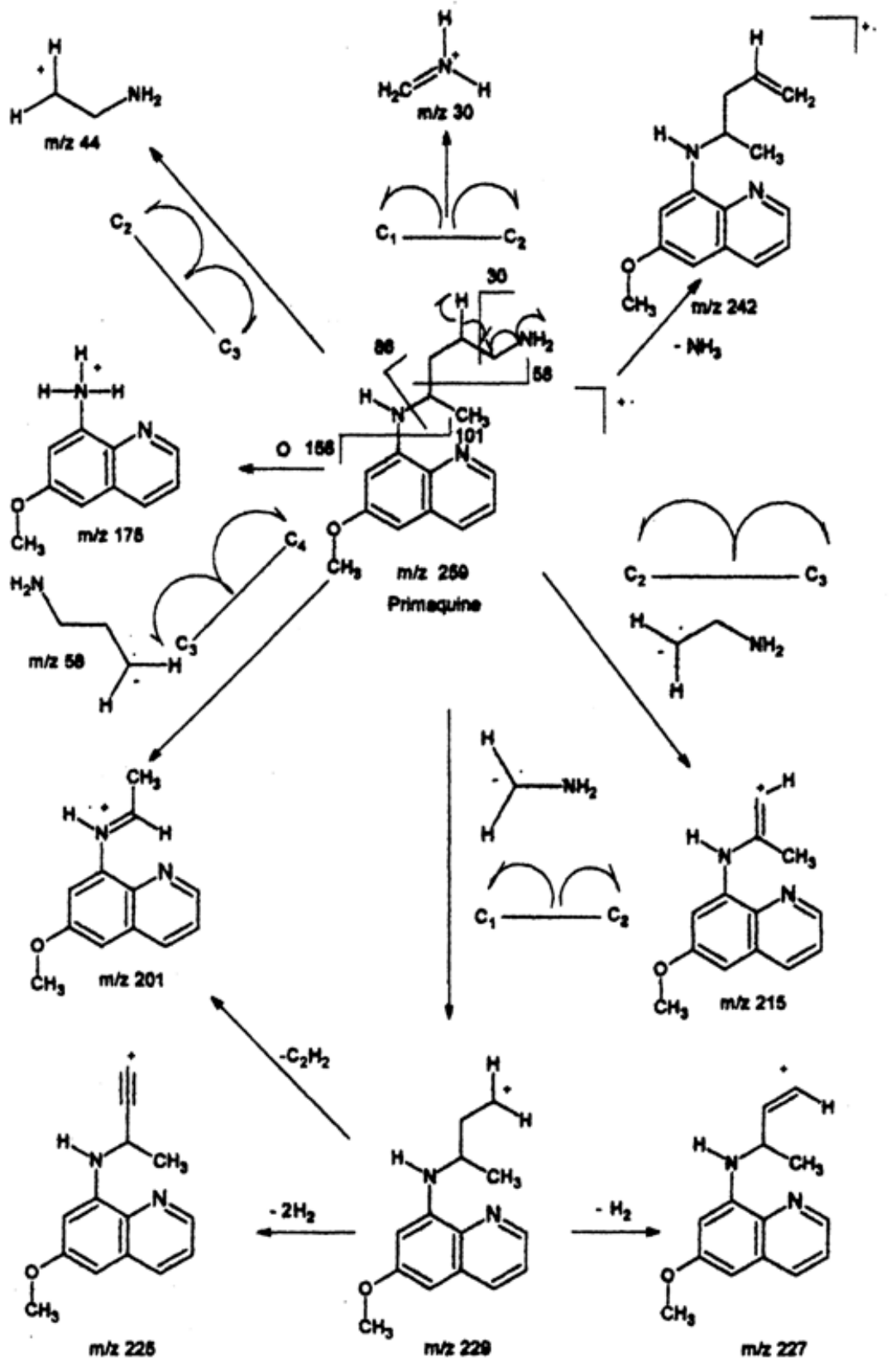

Fig. 3. The main routes of fragmentation for primaquine, as suggested by electron ionization mass spectrometry

The ion at $\mathrm{m} / \mathrm{z} 259$ is the molecular ion of primaquine and quinocide. The other ions found in the mass spectra are electron impact fragments of the molecule. The proposed fragmentation of the molecules of primaquine and quinocide are shown in Figs. 3 and 4 respectively.

The base peak in the mass spectrum of primaquine was found to be at $\mathrm{m} / \mathrm{z} 201$ in the mass spectrum of the positional isomer the base peak was found to be at $\mathrm{m} / \mathrm{z} 187$. 
Which of the fragment ions observed in the two mass spectra of primaquine and quinocide are formed depends on the location of the charge and the energy distribution in the molecular ion.

The non-bonding orbital available on the three nitrogen atoms and on an

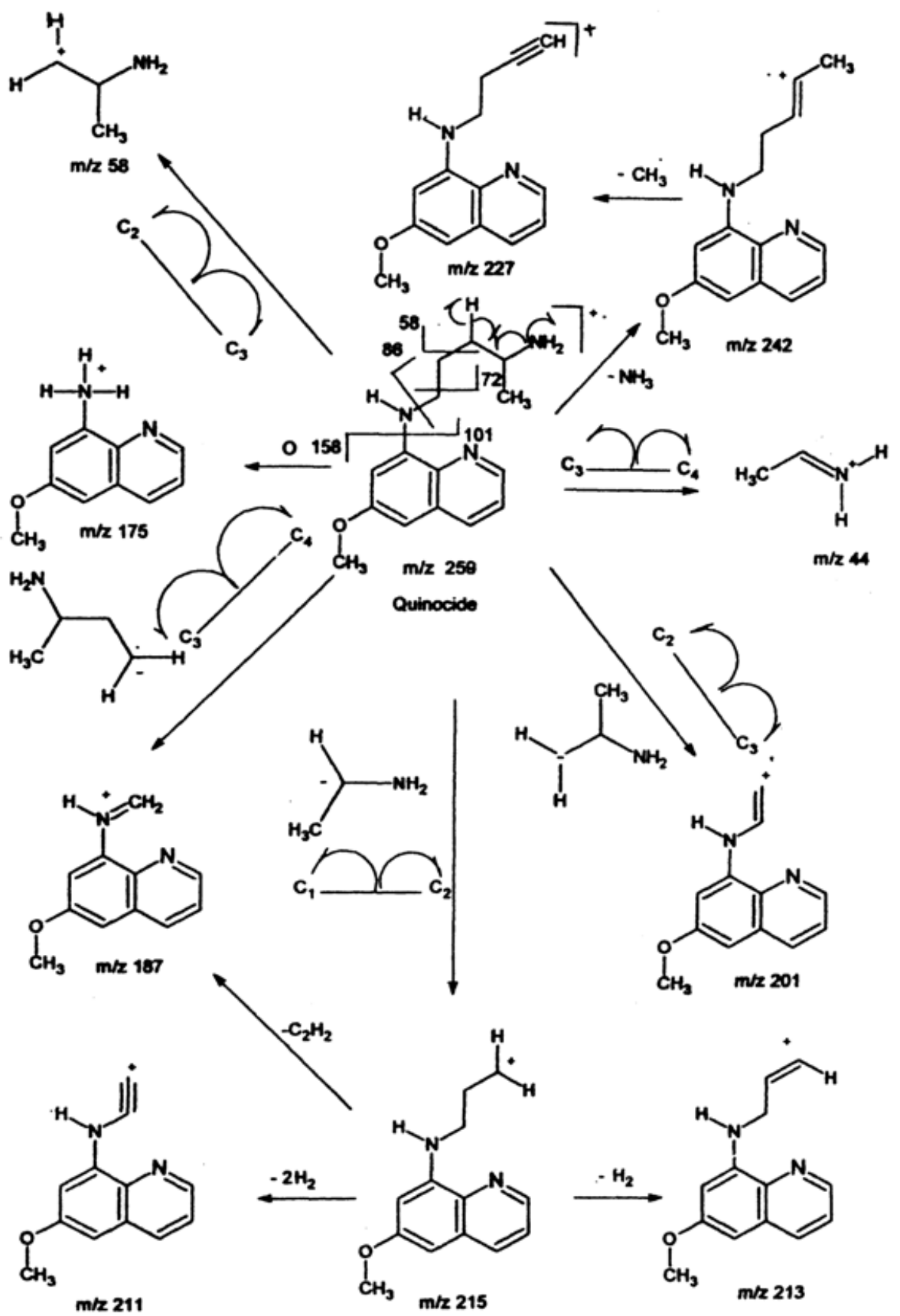

Fig. 4. The main routes of fragmentation for quinocide, as suggested by electron ionization mass spectrometry 
oxygen atom are certainly sites of electron expulsion upon ionization. When the charge is at the primary amine nitrogen, homolytic $\mathrm{C}_{3}-\mathrm{C}_{4}$ bond cleavage takes place.

In addition, when the secondary amine nitrogen is ionized, $\mathrm{C}_{1}-\mathrm{C}_{2}$ bond cleavage is observed. The fragment ions are formed with $\mathrm{m} / \mathrm{z} 201$ and $\mathrm{m} / \mathrm{z} 187$ from the molecular ions of primaquine and quinocide, respectively.

The ions found at $\mathrm{m} / \mathrm{z} 30$ and $\mathrm{m} / \mathrm{z} 44$ are importnat to identify and also to characterize the mass spectra of the two compounds, primaquine and the main contaminant quinocide. Formation of fragment ions with $\mathrm{m} / \mathrm{z} 44$ from primaquine and quinocide results in two different fragment ions, as illustrated in Figs. 3 and 4. These fragment ions are formed due to bond cleavage at two different sites in the molecules. There is a minor portion of the ions at the $\mathrm{m} / \mathrm{z} 44$ from primaquine observed. The nominal mass of ions found at $\mathrm{m} / \mathrm{z} 44 \mathrm{can}$ in principal correspond to several ions, e.g., $\mathrm{C}_{2} \mathrm{H}_{6} \mathrm{~N}^{+}, \mathrm{CO}_{2}^{+}, \mathrm{N}_{2} \mathrm{O}^{+}, \mathrm{C}_{2} \mathrm{H}_{4} \mathrm{O}^{+}$and $\mathrm{C}_{3} \mathrm{H}_{8}^{+}$. The accurate masses of these ions are shown in Table-1. The resolving power necessary to separate $\mathrm{C}_{2} \mathrm{H}_{6} \mathrm{~N}^{+}$from the other ions is $732,900,1850$ and 3500 , respectively. No peaks corresponding to $\mathrm{N}_{2} \mathrm{O}^{+}, \mathrm{C}_{2} \mathrm{H}_{4} \mathrm{O}^{+}$or $\mathrm{C}_{3} \mathrm{H}_{8}^{+}$are observed in the mass spectra of the two compounds (not shown).

TABLE-1

ACCURATE MASS OF DIFFERENT IONS AT THE NOMINAL MASS m/z 44

\begin{tabular}{lc}
\hline Compound & Accurate mass \\
\hline $\mathrm{CO}_{2}^{+}$ & 43.989829 \\
$\mathrm{C}_{2} \mathrm{H}_{6} \mathrm{~N}^{+}$ & 44.050024 \\
$\mathrm{~N}_{2} \mathrm{O}^{+}$ & 44.001062 \\
$\mathrm{C}_{2} \mathrm{H}_{4} \mathrm{O}^{+}$ & 44.026214 \\
$\mathrm{C}_{3} \mathrm{H}_{8}^{+}$ & 44.062600 \\
\hline
\end{tabular}

The main conclusion from these experiments is, therefore, that the ions found at $\mathrm{m} / \mathrm{z} 44$ correspond to $\mathrm{CO}_{2}^{+}$and $\mathrm{C}_{2} \mathrm{H}_{6} \mathrm{~N}^{+}$. Carbon dioxide is assumed to come from the oil diffusion pumps, and is observed only in small amounts in the mass spectra of the two compounds.

The $\mathrm{C}_{2} \mathrm{H}_{6} \mathrm{~N}^{+}$ions are not observed in the mass spectrum of primaquine, which implies that $\mathrm{C}_{2}-\mathrm{C}_{3}$ bond cleavage results in fragment ions in which the charge is located in the largest fragment, found to be at $\mathrm{m} / \mathrm{z} 215$. A similar situation is observed for quinocide, homolytic bond cleavage of the $\mathrm{C}_{2}-\mathrm{C}_{3}$ bond results in ions with $\mathrm{m} / \mathrm{z} 201$ and not $\mathrm{NH}_{2}(\mathrm{CH})\left(\mathrm{CH}_{3}\right)\left(\mathrm{CH}_{2}\right)^{+}$ions with $\mathrm{m} / \mathrm{z}$ 58. The mass spectrum of quinocide has about the same amount of the fragment ions $\mathrm{C}_{2} \mathrm{H}_{6} \mathrm{~N}^{+}$ at $\mathrm{m} / \mathrm{z} 44$ as primaquine at $\mathrm{m} / \mathrm{z} 30, \mathrm{CH}_{4} \mathrm{~N}^{+}$, which are caused by $\mathrm{C}_{3}-\mathrm{C}_{4} \Phi$ bond cleavage.

Since these fragment ions are observed in the two mass spectra of primaquine and quinocide it supports the proposed fragmentation mechanisms illustrated in the schemes shown in Figs. 3 and 4. The mass spectrum of quinocide has significantly greater amount of the fragment ions at m/z 242 and 227 than the 
mass spectra of primaquine. The fragmentation mechanisms illustrated in the schemes in Fig. 3 and Fig. 4 show that ions at $\mathrm{m} / \mathrm{z} 242$ in quinocide have different structures than in primaquine. The ions at $\mathrm{m} / \mathrm{z} 227$, therefore, have different origins in quinocide and in primaquine.

Elimination of $\mathrm{NH}_{3}$ is observed from the molecular ions of both primaquine and quinocide, which may imply corssing of the $\mathrm{k} v s$. E curves. Elimination of ammonia can take place via., 1,2-elimination reaction, which is thermally induced or an electron impact-induced 1,4-elimination reaction.

A third mechanism proceeds via. some high energy processes which are initiated by a reversible transfer of hydrogen from the secondary amine or the methyl group in $\mathrm{C}(1)$. but this reaction is probably not due to steric interactions.

One of the main conclusions that can be drawn from these experiments and discussions is that $\mathrm{C}_{1}-\mathrm{C}_{2}$ and $\mathrm{C}_{3}-\mathrm{C}_{4} \sigma$ bond cleavage is the main fragmentation of the molecular ions of primaquine and quinocide, respectively. It indicates formation of fragment ions at m/z 30 and 201 and m/z 44 and 187 from the molecular ions of primaquine and quinocide, respectively. This information is important for distinguishing between the two positional isomers. Elimination of ammonia is observed in significant amounts from both molecular ions.

\section{Conclusion}

It is concluded that the main contaminant in the drug primaquine di-phosphate used in pharmaceutical production is not an enantiomer as believed previously, but the positional isomer quinocide. It can be successfully separated in mixture by GC, and recognized by MS characteristic fragmentation.

Important information for distinguishing between the two positional isomers is the formation of fragment ions at m/z 30 and 201 and m/z 44 and 187 from the molecular ions of primaquine and quinocide, respectively.

Using GC-MS it is possible to distinguish beyond doubt between the two positional isomers primaquine and quinocide without using the standard substance quinocide.

Primaquine diphosphate is not a racemate but a mixture of positional and stereo isomers. These conclusions are based on GC-MS and on previous analysis using two HPLC systems and LC-MS analysis ${ }^{1}$.

\section{ACKNOWLEDGEMENTS}

The authors are expressing gratitude to Jon Reierstad, Technical Department, University of Oslo, Norway, for technical assistance and to research company Jupiter AS, Norway, for financial support.

\section{REFERENCES}

1. I. Brondz, D. Mantizilas, U. Klein, D. Ekeberg, E. Hvattum, M.N. Lebedeva, F.S. Mikhailitsyn, G.D. Souleimanov and J. Roe, J. Chromatogr. B., 800, 211 (2004).

2. H. Derendorf, M. Scha' fer-Korting, K. Elrod and K.S. Estes, in: Ernst Mutschler (Ed.), Drug Actions Basic Principles and Therapeutic Aspects, Scientific Publishers, Stuttgart, p. 564 (1995). 
3. Martindale, in: R.G. Todd (Ed.), Extra Pharmacopoeia, 25th Edn.,The Pharmaceutical Press, London, p. 315 (1967).

4. R.C. Elderfield, W.J. Gensler, J.D. Head, H.A. Hageman, C.B. Kremer, J.B. Wright, A.D. Holley, B. Williamson, J. Galbreath, J. Wielderhold III, R. Flohardt, S.M. Kupchan, T.A. Williamson and O. Biratein, J. Am. Chem. Soc., 68, 1524 (1946).

5. R.C. Elderfield, H.E. Mertel, R.T. Mitch, I.M. Wempen and E. Werble, J. Am. Chem. Soc., 77, 4816 (1955).

6. M.V. Braude and V.l. Stavrovskaja, J. Gen. Chem. USSR, 26, 999 (1956).

7. M.V. Braude and V.I. Stavrovskaja, Med. Prom., 11, 19 (1957).

8. British Pharmacopoeia, Vol. I, p. 541 (1993).

9. British Pharmacopoeia, 1993, Addendum, p. 2015 (1997).

10. European Pharmacopoeia, 3rd Edn., p. 1385 (1997).

11. British Pharmacopoeia, Vol. I, p. 1285 (2000).

12. European Pharmacopoeia, 3rd Edn., Supplement, p. 1323 (2001).

(Received: 11 September 2004; Accepted: 28 March 2005)

AJC-4154

\section{1th INTERNATIONAL CONFERENCE AND EXHIBITION ON INSTRUMENTAL ANALYSIS}

\section{0-23 OCTOBER, 2005}

BEIJING, CHINA

\section{Contact:}

General Service Office

BCEIA, Roiom 585, 54 Sanlihe Road

PO Box 2143, Beijing 10045, China

E-mail: conf@bceia.org

URL: www.bceia.org.

(k)

Figure 11. (a) The first page (page 1678) of the paper [6]. (b) The page 1679 in the paper [6]. (c) The page 1680 in the paper [6]. (d) The page 1681 in the paper [6]. (e) The page 1682 in the paper [6]. (f) The page 1683 in the paper [6]. (g) The page 1684 in the paper [6]. (h) The page 1685 in the paper [6]. (i) The page 1686 in the paper [6]. (j) The page 1687 in the paper [6]. (k) The last page 1688 of the paper [6].

the acceptance date of the "stolen goods" [3] suggests that the date March 28, 2005 was not chosen by accident. Publication [3] was accepted on March 24, 2005; publication [6] was on hold until publication [3] was accepted. The cooperation between Dongre and AJC is obvious.

\section{Discussion and Conclusions}

Five publishers were discussed in this paper: a relatively small publisher based in India, a medium-sized US-based publisher, two very large international publishers, and a large Asia-based publisher Asian Journal of Chemistry, a Multidisciplinary Chemistry (Journal is International Journal and publishes from India). However, despite their 
different sizes and locations, the breaching of authors' rights and poor publication ethics were common to them all; moreover, there are no grounds to believe that other publishers are free of such behavior. The cases of outright stealing (clearly and completely) are relatively rare. However, [1] demonstrated without doubt that Dongre et al. described in [3] the analysis of a substance that they had never had in their hands, and that therefore they had not in fact analyzed. Together with the accusation made against them in [2], it is clear that Dongre et al. had the opportunity to read the manuscript for publication [6] before publication of this paper and someone in AJC gave him (Dongre et al.) this opportunity. By analyzing the documents shown in Figures 9-11, there is a clear suspicion of corruption in publisher of AJC. Moreover, the EIC of AJC could not explain the difference in acceptance dates of paper [6] noted in his letter (Figure 9) and that printed on the last page of the paper [6] (Figure 11(k)).

Thus, Figures 1-11 serve to catalogue well-documented breaches of authors' rights by publishers and editors.

Authors who publish continuously over a long period of time are often confronted with these or similar problems, and they (problems) are very difficult to overcome because of the complicity (collegiality or more plainly corruption) that exists among editors. The best example of this is that Mister Chankvetadze, EIC of JPBA, is well aware that publications [3] and [5] are falsifications; but despite this, his efforts are directed at concealing the truth and preserving to hold these in JPBA. The demagogy of Mister Murray, EIC of Analytical Chemistry, is clearly exemplified in [7]. Nearly all editors resist exposing the mistakes of their colleagues. It is difficult to overcome this. However, plagiarism, cheating, fraud, or falsification — whatever we call it —is very sensitive to exposure by names to the public because publishers are concerned about adverse publicity. Exposure by name to the public of those who cheat may be the best tool to eliminate this behavior in publication practices.

All cases of plagiarism, cheating, fraud, and falsification in publications should be properly documented.

Some efforts have already been made in this direction with the introduction of Academic Editors.

\section{References}

[1] Brondz, I. (2012) Analytical Methods in Quality Control of Scientific Publications. American Journal of Analytical Chemistry, 3, 443-447 http://dx.doi.org/10.4236/ajac.2012.36058

[2] Brondz, I. (2011) Historical Overview of Chromatography and Related Techniques in Analysis of Antimalarial Drug Primaquine. Nova Science Publishers, Inc., New York.

[3] Dongre, V.G., Karmuse, P.P., Nimbalkar, M.M., Singh, D. and Kumar, A. (2005) Applications of GC-EI-MS for the Identification and Investigation of Positional Isomer in Primaquine, an Antimalarial Drug. Journal of Pharmaceutical and Biomedical Analysis, 39, 111-116. http://dx.doi.org/10.1016/j.jpba.2005.03.019

[4] Brondz, I. (2013) Analytical Methods in Quality Control of Scientific Publications Part II: The Authors', Reviewers', Editors' Responsibility and the Publishers' Authority. International Journal of Analytical Mass Spectrometry and Chromatography, 1, 81-89. http://dx.doi.org/10.4236/ijamsc.2013.12010

[5] Dongre, V.G., Karmuse, P.P., Rao, P.P. and Kumar, A. (2008) Development and Validation of UPLC Method for Determination of Primaquine Phosphate and Its Impurities. Journal of Pharmaceutical and Biomedical Analysis, 46, 236242. http://dx.doi.org/10.1016/j.jpba.2007.09.012

[6] Brondz, I., Klein, U., Ekeberg, D., Mantzilas, D., Hvattum, E., Schultz, H. and Mikhailitsyn, F.S. (2005) Nature of the Main Contaminant in the Anti-Malaria Drug Primaquine Diphosphate: GC-MS Analysis. Asian Journal of Chemistry, 17, 1678-1688.

[7] Murray, R.W. (2010) There Can Be Shame and Punishment in Copy and Paste. Analytical Chemistry, 82, 7053.

[8] Brondz, I., Ekeberg, D., Karaliova, L., Jennings, I., Hustad, J.A. and Svendsen, R. (2005) Separation of the Positional Isomer Quinocide from the Anti-Malaria Drug Primaquine Using a Discovery ${ }^{\circledR}$ HS-F5 HPLC Column. Trends in Chromatography, 1, 78-81.

[9] Brondz, I. (2009) SFC-MS Analysis of Contaminants in Primaquine Diphosphate Tablets and Spectral UV and NMR Characterizing of Primaquine and Quinocide. In: Csizmadia, E. and Kalnoky, I., Eds., Antimalarial Drugs: Costs, Safety and Efficacy, Nova Science Publishers, Inc., New York, 105-124.

[10] Man, J. (2002) Gutenberg: How One Man Remade the World with Words. John Wiley and Sons, Inc., New York.

[11] Brondz, I., Ekeberg, D., Høiland, K., Bell, D.S. and Annino, A.R. (2007) The Real Nature of the Indole Alkaloids in Cortinarius infractus: Evaluation of Artifact Formation through Solvent Extraction Method Development. Journal of Chromatography A, 1148, 1-7. http://dx.doi.org/10.1016/j.chroma.2007.02.074

[12] Cserháti, T. (2010) Chromatography of Aroma Compounds and Fragrances. Springer-Verlag, Berlin, Heidelberg. http://dx.doi.org/10.1007/978-3-642-01656-1 
Scientific Research Publishing (SCIRP) is one of the largest Open Access journal publishers. It is currently publishing more than 200 open access, online, peer-reviewed journals covering a wide range of academic disciplines. SCIRP serves the worldwide academic communities and contributes to the progress and application of science with its publication.

Other selected journals from SCIRP are listed as below. Submit your manuscript to us via either submit@scirp.org or Online Submission Portal.
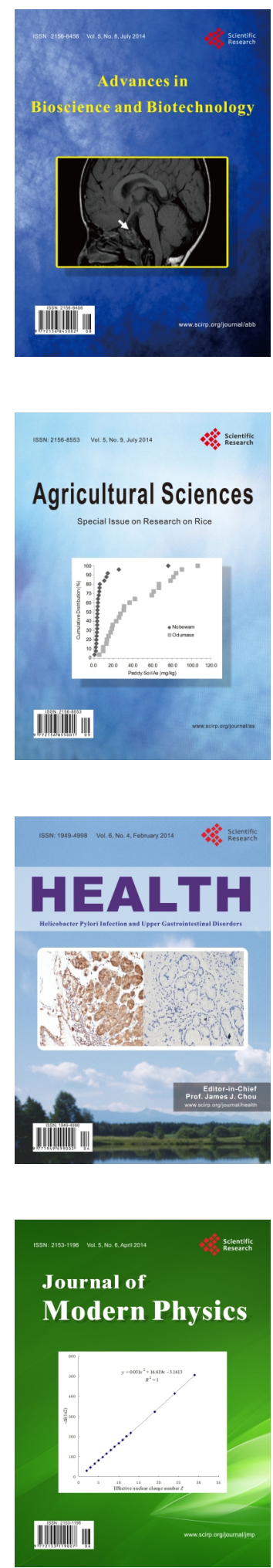
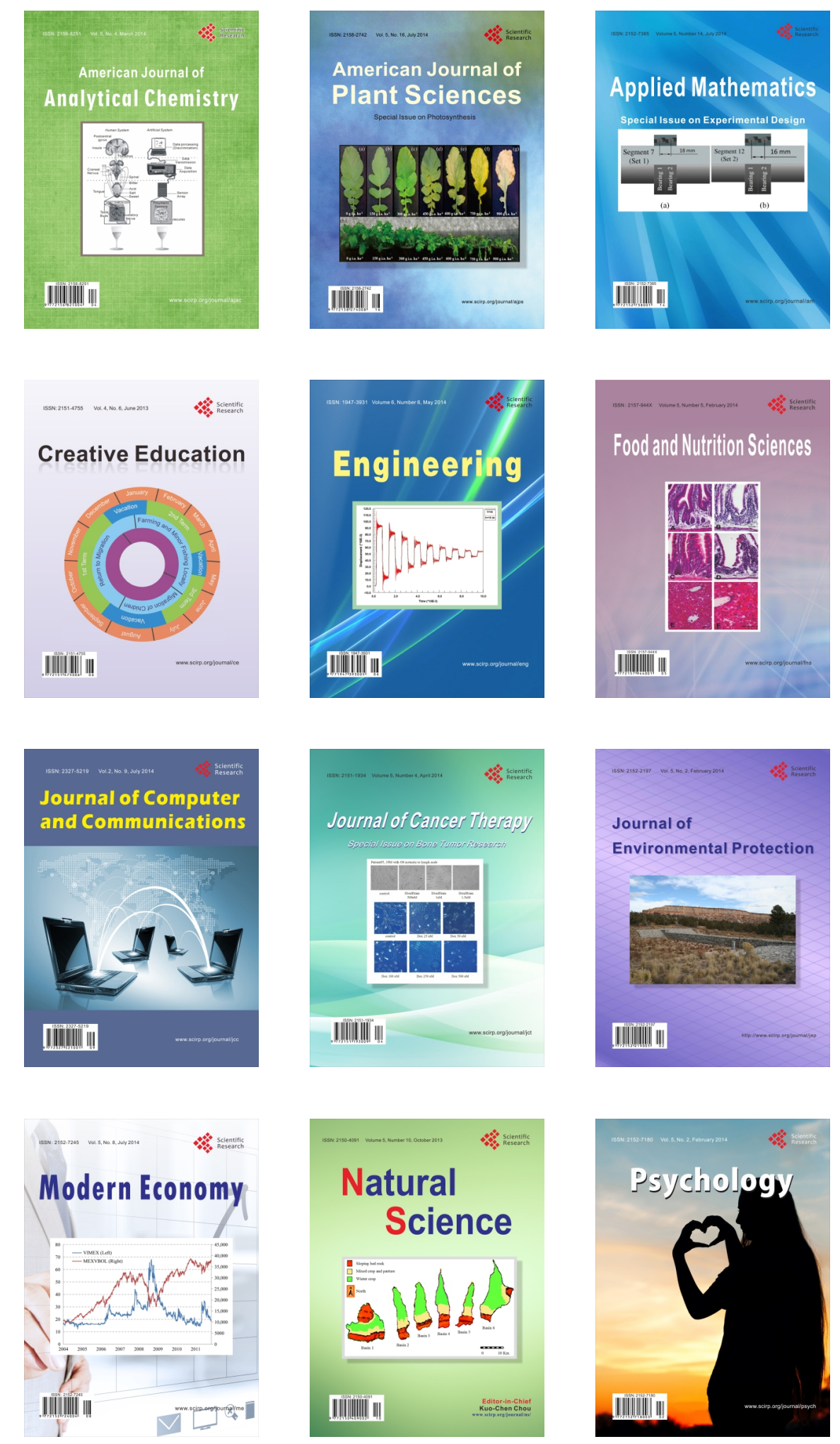